\title{
Prince Charles foreland
}

\section{William S. Bruce F.R.S.E.}

To cite this article: William S. Bruce F.R.S.E. (1907) Prince Charles foreland, Scottish Geographical Magazine, 23:3, 141-156, DOI: 10.1080/00369220708733731

To link to this article: http://dx.doi.org/10.1080/00369220708733731

曲 Published online: 27 Feb 2008.

Submit your article to this journal

LII Article views: 7

Q View related articles ¿

4 Citing articles: 3 View citing articles 
would no longer be felt as it unhappily is to-day. To suggest that our oversea fellow-countrymen will ever willingly expatriate themselves is to disclaim all knowledge of the sentiments dominating them as a whole. Their blood is our blood, all our glorious traditions of the past are theirs also, and with us they share the right to a common heritage. There is no reason why, by an ill-conceived policy, the work of generations of British manhood should be lost to them and us, but there will be no security against the repetition of such a folly until we admit that our great self-governing colonies are already ripe to assist in the government of the Empire they adorn.

Let those who dream of universal peace through the medium of international arbitration abandon their impractical and delusive hopes and work for a consolidated Empire, through which means alone this high object is in practice possible. To my mind universal peace is impossible until one nation not merely occupies so powerful a position as to command deference, but by its liberality and disinterested world-policy compels the respect of the universe. Break up the British Empire, and with the increase in the number of independent states there will be greater scope for avidity and a consequent increased risk of war. Foster its growth and retain it in its integrity, and the peace ideal is not unattainable.

\section{PRINCE CHARLES FORELAND. ${ }^{1}$}

By William S. Bruce, F.R.S.E.

\section{(With Illustrations and Map.)}

ON June the 17th, 1596, Willem Barents-zoon (or Barents) and Heemskerke Hendickszoon discovered Spitsbergen after approaching it from the north-east, probably sighting in the first place the island of Cloven Cliff. Steering southward along the west coast Barents and Heemskerke sighted a steep point on June $25 \mathrm{th}$, and on the 26 th anchored between it and the mainland. This steep point Barents named "Vogelhoeck" because of the large number of birds there. We may therefore quite definitely state that Prince Charles Foreland was discovered on the 25 th of June 1596, only eight days after the sighting of Spitsbergen.

- There appears to be some doubt as to the exact time when this island was named Prince Charles Foreland, but already, in 1612, the British called it so, while the Dutch called it Kijn Island, after a Dutchman who broke his neck there that year. The name Prince Charles Foreland therefore seems to have full historical priority, the island having been named after the son of James vI. of Scotland. Hudson possibly may have given this name to the island, since he visited this part of the Spitsbergen archipelago in 1607. In 1610 the Muscovy Company dispatched Jonas Poole in the Amitie to Bear Island, and missing Bear Island, Poole sighted the south end of Spitsbergen on

1 Outlook Tower and Scottish Oceanographical Lectures, February 13, 1907. 
6th May. On the 21st of May Poole was off the south point of Prince Charles Foreland, which he named Black Point, and landed at Vogel Hook on the 26th of May. From this time until 1775 the Foreland was frequently sighted and doubtlessly landed upon, but still little more was known of it than in the days of Barents. In 1775 Phipps was sent out on a North Polar Expedition by George III. on the recommendation of the Royal Society of London, and it is interesting to note that Horatio Nelson was a midshipman on board the Carcass, one of Phipps's ships. The Foreland was sighted and a peak measured estimated to have an altitude of 4509 feet. ${ }^{1}$ Almost every ship cruising along the west coast of Spitsbergen has sighted the Foreland, and frequent landings and

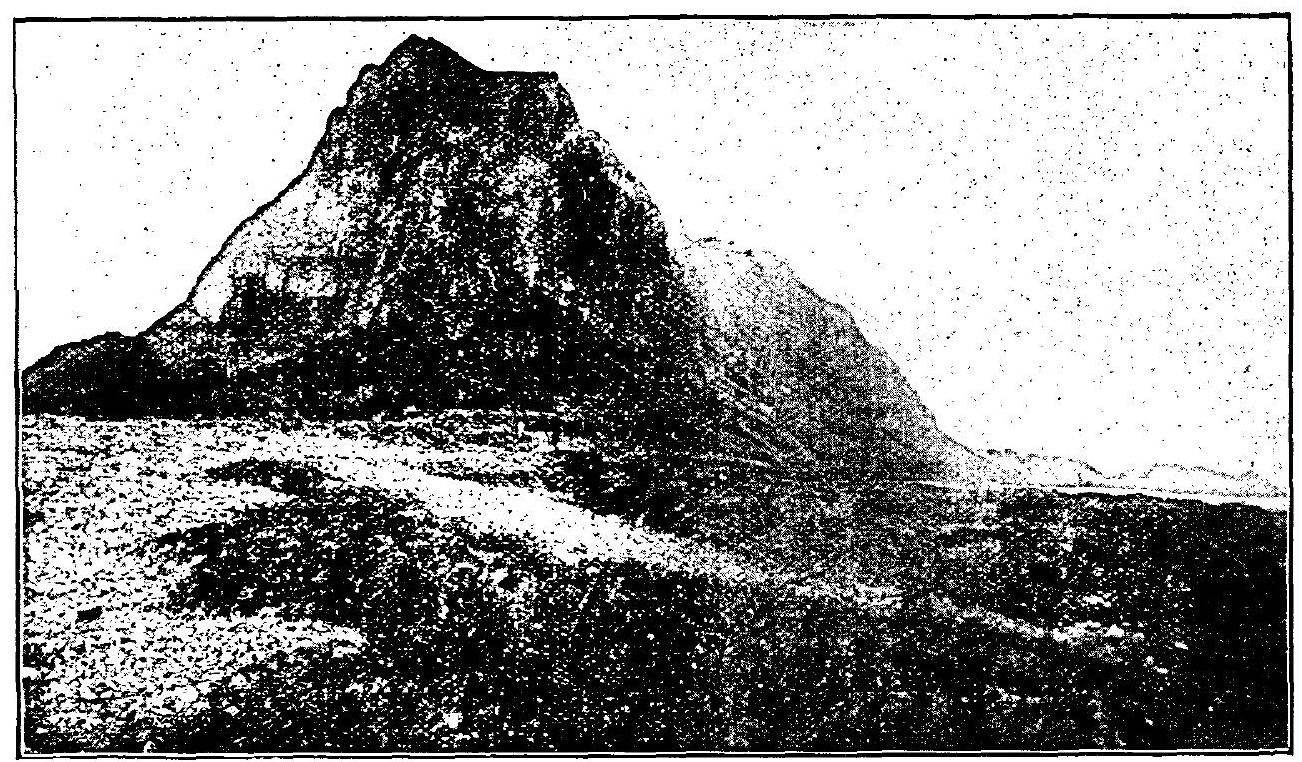

Vogel Hook from NW., discovered by Barents in 1596.

winterings have certainly been made (as I know by my sojourn there last year), but the curious fact remains that up till last year no serious attempt had ever been made to survey this large island, and thus practically all the accounts are from navigators who have only seen the island from a distance, and are therefore very far from accurate.

Scoresby's first landing in an arctic country was on Prince Charles Foreland at Vogel Hook, but on account of bad weather he was obliged to put off with haste, and had difficulty in regaining his ship. He says that "the number of birds seen in the precipices and rocks adjoining the sea was immense; and the noise they made on our approach was quite deafening."

He was also ashore several times in 1818 at Milre Cape, a prominent point on the mainland opposite Vogel Hook, probably having connection 
with it by a submarine ridge. He rightly describes this as being " a remarkable point, and dangerous to shipping going into King's Bay or Cross Bay, being surrounded by blind rocks."

"The middle of Charles' Island," says Scoresby, " is occupied by a mountain chain of about thirty miles in length, rising on the west side from the sea, and on the east from a small strip of table-land, only a few feet above the level of the ocean. In some parts of the coast, indeed, the table-land, from which the mountains take their rise, is even below the level of the high-water mark, and is only prevented from being covered by a natural sea-bank of shingle, thrown up in many places to the height of ten or fifteen feet."

Scoresby gives further descriptions of Prince Charles Foreland, emphasising particularly the strange hill named the "Devil's Thumb"; but his description saying that "the highest mountains take their rise at the water's edge," is scarcely correct, for a series of raised beaches intervene between them and the sea. But this further description is good, where he says, "The points formed by two or three of them are so fine, that the imagination is at a loss to conceive of a place, on which an adventurer, attempting the hazardous exploit of climbing one of the summits, might rest. Were such an undertaking practicable, it is evident it could not be effected without imminent danger. Besides extraordinary courage and strength requisite in the adventurer, such an attempt would need the utmost powers of exertion, as well as the most irresistible perseverance." But probably easier ascents, by way of the great eastern glaciers, could be made than by the precipitous western crags. $^{1}$

One of the best general descriptions of the island is Lamont's, ${ }^{2}$ where he says, "Prince Charles Foreland is a long narrow island separated from the mainland by a shallow sound. Although Spitsbergen is eminently a mountainous country it is more properly regarded from a geological point of view as an elevated plateau, whose sides have been broken and cut through by glacier action, to form isolated ridges and pinnacles. It has no great mountain range or backbone. In Prince Charles Foreland we find the nearest approach to such a regular arrangement of hills. And it constitutes a sufficiently striking mountain-range occupying nearly the whole sixty miles' length of the island. On the west side the rise from the sea is abrupt and precipitous, but on the east the descent is more gradual to low ground a few feet above the level of the sea. On the latter side the glaciers have considerably encroached. The chain of mountains is broken towards the southern extremity, and gives place to a low, sandy flat, where numbers of sea-birds congregate in summer. With the telescope we could make out the wreck of a timber-vessel, which came from the Petchora river five years ago, had been abandoned at sea by the crew, and was cast up on this shore. About the middle of the island a singular black rock-or rather mountain, for it is 2000 feet high-jutting out into the sea has been termed the 'Devil's Thumb.'

1 An Account of the Arctic Regions. By W. Scoresby, Jun., F.R.S.E., pp. 97, 98 ; and 118, 119. Edinburgh, 1820.

2 Yachting in Arctic Seas, by James Lamont. 1876. Section III., pp. 229, 230. 
Some of these mountains rear their needle-like shafts to an elevation of from 3000 to 4000 feet."

Baron Nordenskjöld explored Foreland Sound in a boat in 1868, and sailed through it with his ship in 1872 ; while Lamont navigated it with his yacht the Diana in 1869 ; Conway in 1898 and the Prince of Monaco in 1899 also ran through with steam launches.

Dr. A. G. Nathorst was the first in 1898 to attempt anything like a systematic investigation of the island, but these observations were only over a period of two or three hours during a summer night when he sent a small party ashore from his ship the Antarctic. ${ }^{1}$ Nevertheless he was able to give us a more concrete idea of this unknown land than any of his predecessors. Here is his description of the discoveries of his party ${ }^{2}:-$

" 24 th July 1898.-In the afternoon we were sounding to the southwest of Prince Charles Foreland where the depth was 240 metres, and afterwards I headed for this land to effect a landing. The south part of the Foreland greatly resembles the north point of Duck Island (Andö, Tromsö). Here there is an isolated set of mountains, and after that a low plain, whilst to the north of this begins a veritable land of mountains. This is indeed a fine range of peaks with glaciers between them. We headed for a bay situated between two peaks called 'Sommet Fourelin' and 'Sommet Rond' by the French Expedition in La Manche in 1892. I think it is appropriate to call this bay after that vessel. At 11.30 P.M. our ship was headed into the harbour and one of the large boats was sent ashore with Haslam aft and four oars, together with G. Anderson, Hesselman, and J. G. Anderson. Of course no extended exploration conld be made as the whole landing lasted only a couple of hours, but from a geological point of view I thought it was desirable to get to know if the Hecla-Hook formation was on the west coast of the Foreland too. I remained on the bridge until the party had landed at one o'clock on the morning of the $25 \mathrm{th}$, and then $I$ went to bed. At 3.30 A.Mr. I was awakened by the captain saying that the landing party had returned. The geological observations were in accordance with what we had expected, and the botanists had made a rich collection, which we had not expected. Up to this time the Foreland has been said to have very little vegetation, two phanerogams only having been known on the island. It was therefore surprising that G. Anderson and Hesselman in these three hours had found no fewer than twenty-nine species. Of birds, the eiders were common and the lumnefaglar were very numerous.

"Then we headed for the west and took a sounding at noon of 1474 fathoms about 28 miles outside the Foreland."

Garwood; who visited Spitsbergen with Gregory on Conway's Expedition, writing to me on June 18, 1906, says, as far as he remembers, "Prince Charles Foreland is composed of Hecla-Hoek beds. Those

1 Formerly called Cap Nor, and renamed Antarctic, 1893, by Svend Foyn previous to her first Antarctic cruise 1894-1895; afterwards Dr. Otto Nordenskjöld's ill-fated ship during his memorable Antarctic Expedition 1901-1903.

2 Translation from Tva Somrar Norra Ischafvet, etc., by A. G. Nathorst. Stocklolm, 1900. Vol, i. pp. 187-188. 
horribly uncompromising slates, quartz bands, and schists in which I was never able to get anything definite, though I have found curious oolitic beds from these rocks in Hornsund Bay. I know that the rocks of the main island opposite are Hecla-Hoek, and although I never landed on Prince Charles Foreland (except when we touched bottom in our launch), I have notes that the rocks coming down to the water on the. east side are almost certainly Hecla-Hoek beds. I only state this for what it is worth."

Last summer His Serene Highness the Prince of Monaco invited me to accompany him now for the third time on a voyage to Spitsbergen. I gladly accepted His Highness's invitation, but pointed out that I would like to be associated with some definite work, and suggested, among other alternatives, that he should land me with two assistants on Prince Charles Foreland in order to make a thorough investigation of that practically unknown island. The Prince at once accepted my suggestion, and having chosen two assistants I set about making preparations, in the first place for a systematic geodetic survey of a definite portion of the island, and secondly for acquiring a more exact knowledge about its geology and natural history. My assistants were Mr. Gilbert Kerr, lately piper and taxidermist to the Scotia, and Mr. Ernest A. Miller, a young electrical engineer. On 27 th of June the Princesse Alice steamed into Granton, and on the 28th took her departure with the Scottish party on board.

After a somewhat cold, bleak, and choppy passage-typical of the North Sea-the Princesse Alice reached Bergen. on 30th of June. Here the Prince took on board another exploring party, Norwegians, headed by Captain Isachsen of the Norwegian cavalry, who had previously seen arctic service with Captain Sverdrup; and Lieutenant Staxerud, a young Norwegian infantry officer, employed in the geodetic service of the Geographical Society of Christiania. In all the Norwegian party consisted of ten men, who were to take up the exploration of the northwestern corner of Spitsbergen, lying between Close Cove, ${ }^{1}$ Smerenburg Sound, Red and Liefde Bays. Tromsö was reached on the 9 th of July, and at 1.30 P.M. on 11 th July the south end of Prince Charles Foreland was sighted. From our noon position we steered for the north end of the Foreland, Vogel Hook (or Fair Foreland), and between six and seven in the evening were running fairly close to the shore north of Cape Sietoe. At 7.15 P.M. we were off the north-west point of the Foreland, which bore S. $40^{\circ} \mathrm{W}$. about two miles, and on sounding obtained ten fathoms, having had eight fathoms just previously closer to the land. About 8.30 P.M. we were off Quade Hook, and finally, after some difficulty on account of the rapidly shelving bottom, anchored in Coal Haven, King's Bay, about 11.30 P.M. Just after anchoring there were several white whales near the ship, and the Prince lowered a whale boat with Wedderburn in charge to try to secure one. Next day Isachsen and his party left by the Kvedfjord (a small steamer chartered by His Highness) for Close Cove, while

I Close Cove, so named by Pool, 1610, and Ebeltoft's Harbour, named by him Cross Road. British Admiralty Chart and other modern charts call Close Cove, Cross Bay. Vide No Mfan's Land, by Sir Martin Conway. Cambridge University Press, 1906.

voL. XXIII. 
Captain Carr, Professor Hergesell, and I went ashore to make observations with the theodolite for the ascent of a pilot balloon which had been liberated from the ship. ${ }^{1}$ Afterwards I made a short excursion towards a rather remarkable waterfall, which fell over the edge of a glacier icecliff about two miles from the shore; and it is interesting to note that although a very large volume of water was coming over the ice at this time, that at about midnight, when $I$ was in the crow's-nest and could get a good view of the same place from that elevated position, no water at all was coming over the cliff. The small river from this source, that ran into Coal Haven, was also practically dry. Some doubt may exist as to the cause of this sudden stoppage of the flow of water, but it may be sufficiently accounted for by a touch of frost, which had stopped the surface thawing of the glacier caused by the brilliant sun during the day. On July 14th the Princesse Alice left King's Bay for Close Cove, and at about 1 P.M. the Scottish party left on board the Kredfjord for Prince Charles Foreland.

The Foreland being practically unknown, it was with some difficulty, especially in view of the soundings obtained, that we found a suitable landing-place. A suitable place was, however, eventually found on the east coast about three miles from the north end of the island. By about 2 A.Mr. we had succeeded in landing all our equipment from the Kvedfjord, and she steamed back to the Princesse Alice in Close Cove, leaving Kerr, Miller, and myself to set up camp. Next day was spent mostly in arranging our stores and in making plans for excursions for the purpose of surveying the island. One excursion was made that evening northward along the shore for a distance of about two miles, and a start was made at the survey. On the next two days other excursions were made westward, and we reached the highest point between the two sides of the island, in a narrow gorge, which we called "Windy Gowl," on account of its resemblance as a wind funnel to the place of the same name in the neighbourhood of Edinburgh. On the 17 th we set to work more seriously, and shifted camp from the east coast to the neighbourhood of Windy Gowl. We carried no tent, because the extraordinarily rough nature of the ground prevented us taking more than our instruments, a few provisions, and sleeping sacks. The country over which we passed was almost absolutely barren, there being hardly a plant along the whole route, and only two birds were seen, namely, one purple sandpiper and one Arctic skua. On settling down for the night we had three other visitors, namely, two skuas and one fulmar petrel.

The journey was a somewhat laborious one, the distance of three or four miles having taken us over seven hours. The weather was brilliantly fine and the sun scorchingly hot, so that we divested ourselves of as much clothing as possible, and even then sweated it out. There was bright sun all night, with a cloudless sky and a light westerly air. The scene from Windy Gowl was a striking one. To the eastward we looked back over the dreary stony plains we had crossed, and beyond

1 Vide H.S.H. the Prince of Monaco's lecture on "Meteorological Researches in the High Atmosphere," Edinburgh, 17th January 1907, printed in the present issue, p. 113. 
the Foreland Sound over the picturesque glacier-clad mainland of Spitsbergen in the neighbourhood of King's Bay. To the westward, beyond a less extensive but more fertile plain broken by several lagoons along the shore, stretched the calm western ocean, with no land between us and Greenland, and I may say at this time with no ice in sight. On 18th July I sent Kerr and Miller back to the base camp for more stores, while I descended to the west coast and explored northward for some distance, making many preliminary observations and securing a fox and a pink-footed gosling. The west coast was evidently very much more inhabited than the east, for I came across several gaggles of pink-footed geese, as well as eiders, purple sandpipers, and snow buntings. I got back to camp about 11 P.M. in cold and misty weather, and Windy Gowl keeping up its reputation, compelled us to shift camp about midnight and go down to the plain below. Even there, sheltered as we were, we found the night cold enough without a tent.

Having taken longitude observations at this third camp on 20 th July at about 9 A.Mr., we started back again unloaded at 10 A.M. for the base camp, doing the homeward journey, which had taken us seven hours when loaded, in about two hours. With all possible haste we launched our boat, carrying with us a tent, and loading her well up with sufficient provisions for a week. Then putting out to sea, we steered northward in order to reach the west coast of the island in the vicinity of the camp we had left in the morning. At Vogel Hook we were compelled to run for shelter into a cove, on account of a heavy sea and wind which got up from the westward. We were ashore for about two hours, investigating the wonderful bird rookeries, first discovered by Barents in 1596.

The vegetation was luxuriant with rich mosses, scurvy grass, and many Arctic plants. Birds were countless-Bruennich's guillemots, puffins, little auks, dovekeis, kittiwake gulls, burgomaster gulls, skuas, fulmar petrels, pink-footed geese, purple sandpipers, and snow buntings. The sea and wind subsiding somewhat, we continued our course round Vogel Hook to the westward, and with some difficulty effected a landing about one mile south of Vogel Hook on the west coast, as there was too much sea for us to continue our voyage southward. It became necessary therefore to push southward overland, that we might reach the camp gear which we had left in the morning and bring it back to this new camp further to the north. It was fortunate that we had our tent this night, for it began to rain, a rain which was to continue almost without halting for the next fortnight.

The camp was a most picturesque one, lying vear the rugged, rockbound, reefy shore, on which the wild western sea broke furiously, threatening our boats and gear, which we had to haul well up on shore that they might not be carried away. Rising at the back of us was a short and sharp talus, surmounted by a precipitous cliff of hard old sandstone, probably belonging to the Hekla Hook series. The innumerable birds in these cliffs gave us a continual concert with their myriad voices, while the barking of foxes, curious at our intrusion, resounded from the caverned taluses of massive fallen rocks; every now and then one more curious than the rest would approach us, though with the greatest 
caution. We discovered two lairs of foxes in the talus, and attempted to dig them out, following their position by their continuous growling and barking. It was soon obvious, however, that this attempt was absolutely futile, for the lairs communicated with one another by endless galleries between the interstices of the large loose rocks.

We had now been ashore for a week, and even in this short time had recorded more definite information of Prince Charles Foreland than we

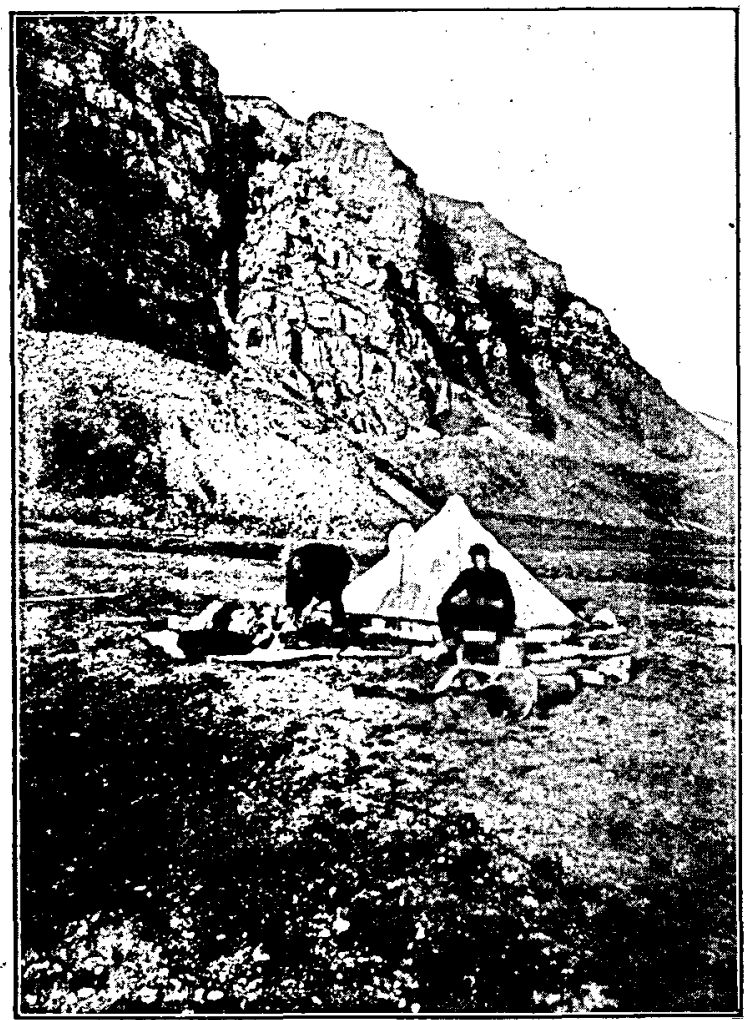

Scottish party's camp on west coast one mile south of Vogel Hook.

had been able to gather together from the books and records of more than three centuries. We had made a survey in the neighbourhood of Vogel Hook; we had some more exact idea of the nature of the rocks; we knew definitely many of the mammals and birds that inhabited the island; and had collected up to this time twenty-four species of flowering plants.

We remained at this camp until the 1st of August, during which time the weather was continuously bad. Gale followed gale and heavy seas broke on the reefy shore, blowing the spray right over the lower land. Fog and mist prevailed almost continuously, and heavy rain was 
the order of the day. Occasionally for an hour there might be a blink of sunshine, only to be followed again by thick, wet, stormy weather. An idea of the stormy weather may be had from the fact that we were never able during this fortnight even to think of launching the boat. On the 31st of July, however, we actually had a chance of attempting it, but after trying twice found it impossible owing to the heavy seas. If it was at all possible, we were due at the base camp that night, as the Prince had arranged to call there on the 1st of August to see how we were getting on. We were preparing to walk across when the weather got worse and we had to abandon all thought even of this landward march. Although we were able to do little in the way of survey, we made a number of local excursions and got to know intimately the whole of the north end of the Foreland. We collected plants and, cramped up in our tent, pressed quite a number. ${ }^{1}$ We also made a complete collection of the rocks ${ }^{2}$ of the neighbourhood, and searched long but vainly for fossils, thus confirming the records of Nathorst and Garwood as to the sterility of these beds. Several foxes were shot, for they became more dariug day by day as their young grew more mature and able to look after themselves. Altogether we saw fully a hundred foxes in the course of this fortnight.

There are two kinds of foxes in Prince Charles Foreland as in the rest of Spitsbergen, where there may also be a third. The two on the Foreland are probably dimorphic forms of the same species. One is a bluish-grey colour all over, while the other appears to be what is known in Russia as the Cross Fox. On its under parts it is white, but down the back from the tip of the nose to the end of the tail runs a broad pale brownish band, which is crossed by two similar bands in the limb regions. From the many adults and young that we saw it would appear at least to be the rule that the uniformly dark-coloured fox breeds more or less separately from the lighter cross form. We have at least no record of having seen mixed parents or litters. This may even point to their being separate varieties. Towards the end of August several very light cross foxes were seen, and one was shot.

Foxes were the only mammals we had seen on the island till now, but we met with the bones of reindeer and bears, and saw an occasional seal in the water, but later on I saw two reindeer. Birds were, as I have said, plentiful, and we had many opportunities in this veritable Bird-land of recording the species to be found and of watching their habits. On the 25 th of July the young guillemots, who were for the most part already hatched when we arrived, began to take to the water, and by midnight several hundreds, perhaps thousands, were swimming about with their parents who came down with them. Those which dropped on the land were at once seized by burgomaster gulls or foxes, both of which lay constantly in wait for a dainty meal of young loom. The burgies also attacked the young loom in the water, but here the parents made a vigorous defence and drove them off. Kittiwake and burgomaster gulls,

1 The plants are being examined and described by Mr. R. N. Rudmose Brown, B.Sc.

2 The rocks and fossils are being examined and described by Mr. Campbell. 
black guillemots, little auks, razorbills and puffins were all breeding on these cliffs at Vogel Hook and for two miles southward along the west coast of the island. Eider ducks and pink-footed geese, both adults and young, were very numerous along the shores, but curiously enough we never found the nests or eggs of either, except on one occasion when we came upon a single deserted duck's egg. Arctic skuas bred on the plains, where we found their nests, and snow buntings' nests with eggs or young were frequently found in crannies. We found the young, but not the egg, of the purple sandpiper. ${ }^{1}$

There are many graves on this and other parts of the island; the remains of boiling stations and huts; abandoned boats and wreckage-all relics of the former great whaling industry, when Dutch, French, and British settlers. lived and died on this island as on many parts of the mainland of Spitsbergen. Most. of these graves have been burrowed out by foxes, and the skeletons lie exposed in rude lidless coffins, weathered and worn. Here and there is a board or a solitary cross, whose inscription indicates the name and nationality of the dead and the time at which he lived on the Foreland. I have in some cases read dates back to the beginning of the seventeenth century, and this well accords with what we know of the activity of the whaling industry in these parts three hundred years ago.

Like many other Arctic lands there is an abundance of driftwood, especially on the west coast, and one notable feature is that a very large proportion is from the wreckage of wooden boats, possibly mostly wrecked walrus sloops. This, with the invaluable though scattered supply of birch bark, is excellent fuel, and was always used by us whenever possible.

On the 1st August, leaving our camp as it stood and only securing it against weather and the ravages of foxes, we marched over to the base camp, and in the afternoon, as neither the Princesse Alice nor the Kvedfjord had arrived, walked three miles to the southward, where we discovered eight Dutch graves. We also saw two great northern divers-a new record for Spitsbergen. At 9.30 P.M. we sighted the two ships, curiously miraged, and they anchored fully two miles from the land in $5 \frac{1}{2}$ fathoms at 11.30 P.M. Next day the weather was very fine, and at 7 A.r. we were awakened by Wedderburn's welcome Scottish voice outside the tent. He had come ashore with letters and parcels. We were on board about 9 A.M. The Prince was at the gangway to meet us and gave us a hearty greeting. He had visited Wiide Bay and Danes Gat and had met Isachsen's party and Wellman's Expedition. We enjoyed the luxury of a hot bath, and then, after having gathered some necessaries, such as ropes, canvas, etc., we lunched on board at 11 and left for the shore soon after noon. The Prince took his departure at 1 o'clock to the $\mathrm{NW}$. to make a balloon ascent. This was the last we saw of the ships until the 26th of August. In the afternoon I got good sights for longitude, having compared my chronometers with those

1 Proc. Roy. Phys. Soc., "The Mammals and Birds of Prince Charles Foreland," by Wm. S. Bruce, F.R.S.E., read November 26, 1906. 
on board the yacht. The rest of the time was spent in continuing the geodetic work, first of all round the north end of the island joining our eastern with our western survey. We extended the eastern survey to a point about 8 miles southward from the Vogel Hook and the western to a distance southward of over 20 miles. In all we mapped in great detail an area of about 120 square miles, that being, roughly, the northernmost third of the island. ${ }^{1}$

The topographical features of Prince Charles Foreland are striking, and as there is no accurate description given in any publication, it may be well to give a general account of these features as far as we know them at the present date.

The British Admiralty Chart of Spitsbergen, No. 2751, published in 1865 under the superintendence of the late Captain G. H. Richards, with corrections up to 1901, gives our present-day standard map of Prince Charles Foreland. This map is far from correct, and in many ways much less accurate than some of the older maps. Edge's map of Spitsbergen, published in 1625 , reveals details which I know to exist and which have been obliterated in the British Admiralty chart. Edge's map has been recently emphasised by Sir Martin Conway. ${ }^{2}$

Prince Charles Foreland is a long island lying off the west coast of Spitsbergen between King's Bay and Ice Fjord; it is separated from the mainland by a channel known as Foreland Sound, of which we know very little. This channel is, however, certainly so shallow that in parts it may, as has been supposed, present a complete bar to all vessels from 10 or 12 feet of draught. But this is not altogether so certain as has been believed up to the present day, for the series of rough soundings which I took on board the Kvedfjord indicate that we may have 3 or 4 fathoms of water as the least depth of the navigable channel. The water appears on the whole to deepen towards the east coast of the Foreland, but it is dangerous to make many statements, for as yet the channel is entirely unsurveyed. The Prince of Monaco's work in Close Cove and between Close Cove and Vogel Hook, and some soundings $I$ have taken, throw preliminary light on the conformation of sea bottom at the northern end of the Sound.

Making the usual approach to the island from the southward, or probably from a little to the west of sonth, one's first impression is that there are two islands, and one has to be very close to the coast before one can see that there is actually continuous land where at first sight a channel appears to exist. The Foreland stretches from about $78^{\circ} 10^{\prime} \mathrm{N}$. to almost $79^{\circ} \mathrm{N}$, and lies roughly between the longitudes of $10^{\circ}$ and $13^{\circ} \mathrm{E}$. It is divided into three regions, the small hilly portion occupying 6 or 8 miles of its southern extremity, and the extensive flat-lying portion, probably nowhere more than 20 feet above the sea, occupying roughly the next 8 or 10 miles of its length, while the remaining three-quarters of the island consist of an almost continuous

1 This map is in the course of construction, and will be published later. Meantime a reproduction of the latest British Admiralty chart is given.

${ }_{2}$ No Man's Land. Sir Martin Conway. Cambridge University Press. Pp. 334-335. 
range of mountains, extending right up to Vogel Hook-the northern point of the Foreland. This range of mountains, it is interesting to note, contains some of the highest peaks of the Spitsbergen archi-

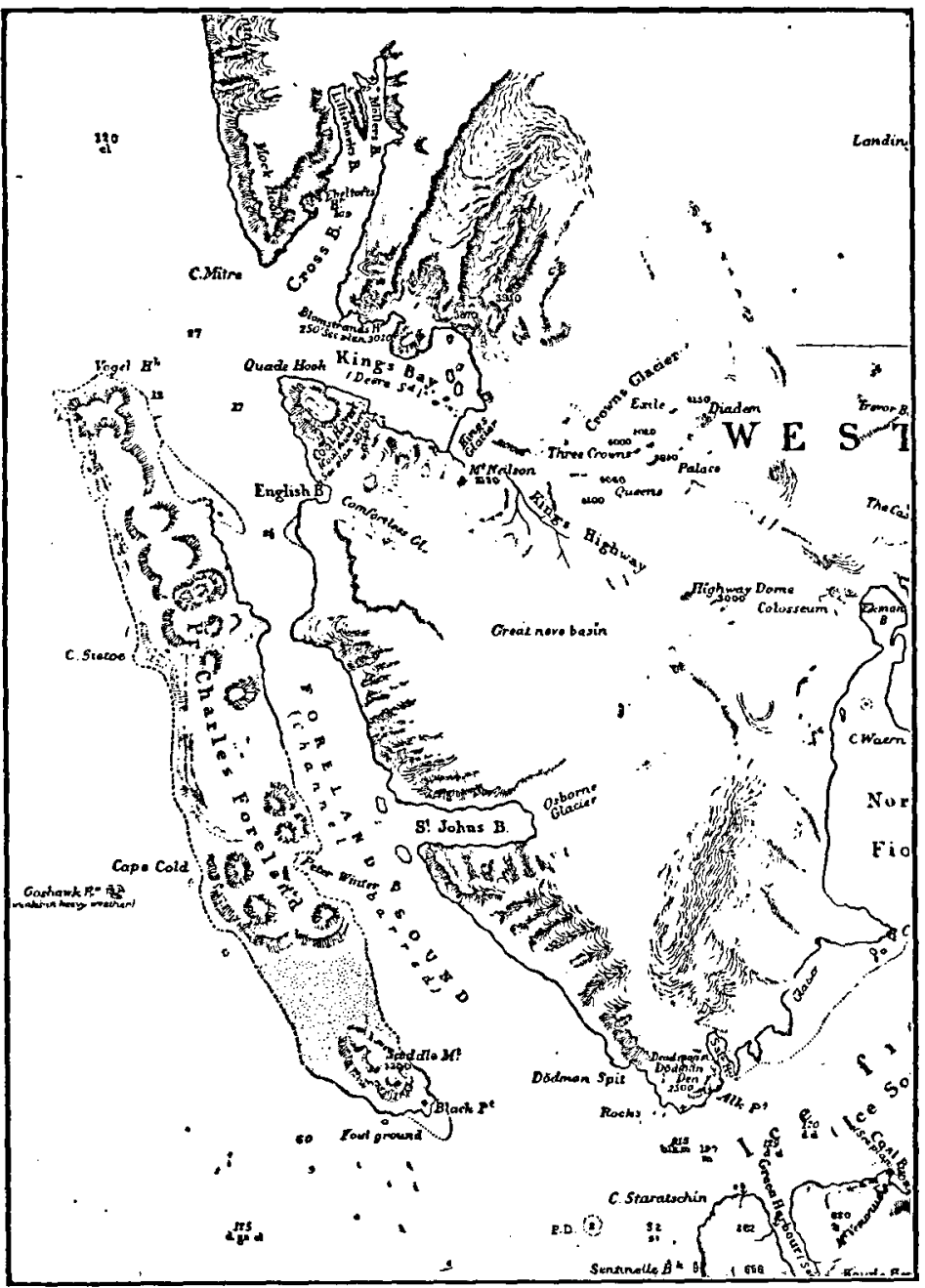

Prince Charles Foreland and part of West Spitsbergen.

(From the Admiralty Chart, 1901.)

pelago. In all the Foreland measures about 50 to 55 miles in length, and has an average breadth of about 6 miles. The mountains forming its backbone rise almost always precipitously, and the ridge is only broken here and there by a rough pass from east to west. They do not, however, as a rule rise straight up from the sea, as they have been 


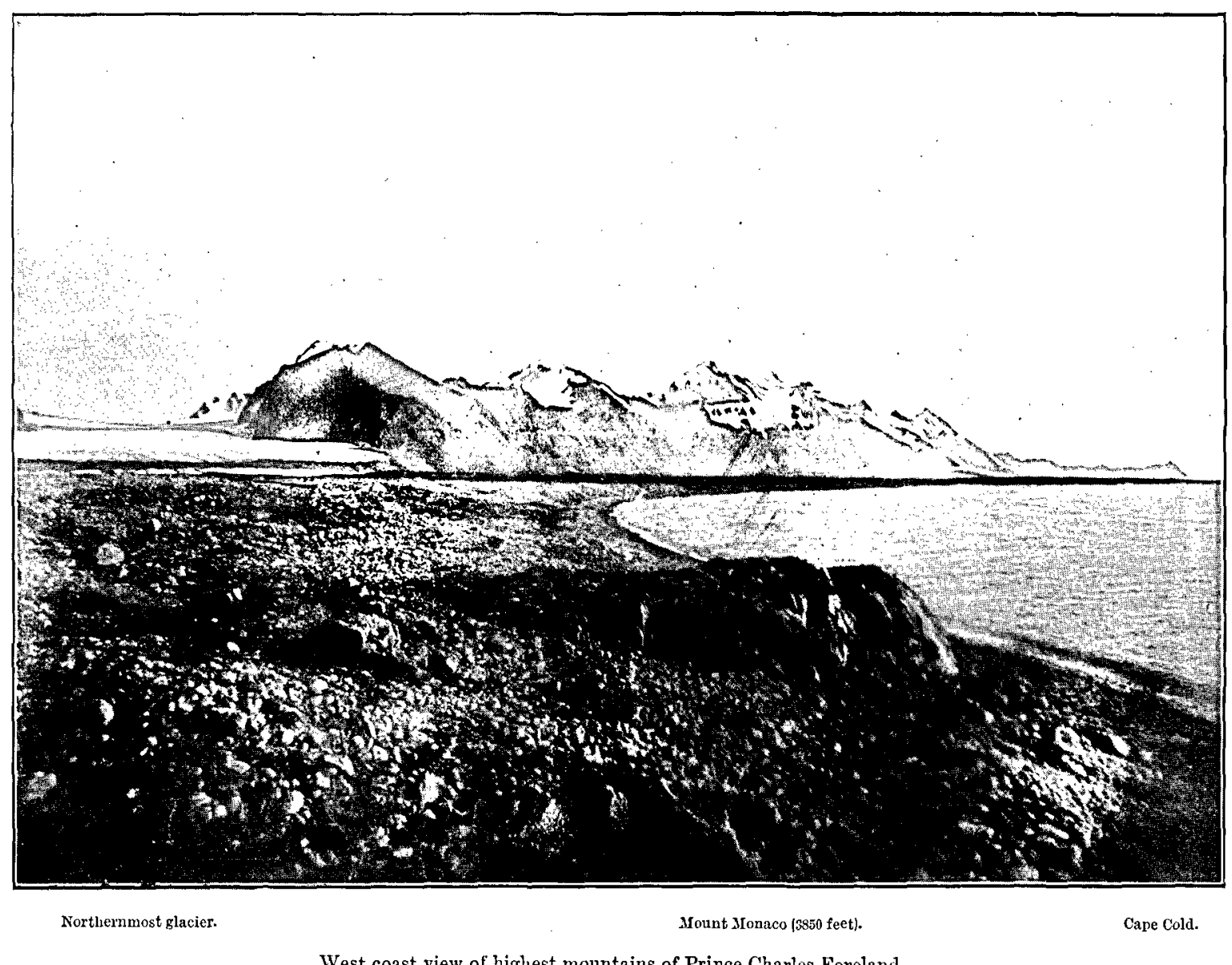

West coast view of highest mountains of Prince Charles Foreland. 
said to do. There is almost invariably along the whole of the west coast a low-lying terraced plain (old raised beaches), the highest terraces of which do not reach a height of more than 50 or 60 feet, and this plain is for the most part half a mile to two miles broad. At the back of the plain rise the mountains with steep taluses and precipitous cliffs. In the middle portion of the Foreland, towards the southern extremity of the mountain range which we are at present dealing with, a number of glaciers find an exit, but none of them reach the sea as they appear to do, to any one sailing along the coast, but terminate on the landward side of these raised beaches. There are no glaciers at all in the northern part of the island. The east coast presents the same features as the west coast with regard to raised beaches, but they are more extensive, the foot of the mountains being sometimes three miles from the sea. The slopes of the mountains also are less precipitous on the eastern than on the western side of the land. The middle third of the Foreland along the east coast is most fully glaciated, and for about 12 miles there is an almost continuous ice-face entering the sea. These great glaciers have their gathering ground amongst the highest of the mountains that exist in the island. The altitude of the highest hill has been estimated by various people, but from exact observations made on the island I was able to measure its height as being 3850 feet.

These terraced raised beaches, which form such a marked characteristic, are dotted over with innumerable shallow fresh-water lakes, and brackish or sea-water lagoons which stretch along the shore. Some of the lagoons are very large, and there is one notable one which appears on Edge's chart, which has been wiped out by more modern cartographers. This lagoon lies on the east coast at the head of a bay opposite English Bay, and is obliterated on all recent maps. It has an excellent entrance from the sea through which a boat, of considerable draught, can enter at high tide. The breadth of this lagoon is fully a mile, while its length is from 3 to 4 miles, and inside the water is of considerable depth. It appeared to me an interesting place for the naturalist: for here, with a good supply of fresh sea-water, protected from the violence of the waves and the rending of driving ice, many forms of animal life find a quiet home. These lagoons, and some of the fresh-water lakes also, are the resort of pink-footed and brent-geese, of eider ducks, and innumerable red-throated divers. Purple sandpipers dart along their shores, and occasionally a rarer bird, as for instance the sanderling and its young, which we discovered breeding here, and which is a new record for Spitsbergen. Kittiwake and burgomaster gulls also, especially after the breeding season, make their resting place here, while arctic terns are to be found flitting across, and nesting in the neighbourhood of, almost every lagoon.

The plains are, moreover, crossed at right angles by a number of burns and rivers which are fed from the snows and glaciers of the higher land. The amount of water present varies considerably in accordance with the time of year. In the early summer there is a very full supply; but as the store of snow becomes diminished later on, and as 
frost binds the land the water which flows from this snow, névé, or even glacier also diminishes, and in autumn it may be difficult to find a suitable camping-place, through lack of even a small spring to furnish necessary water.

There is a marked difference in the vegetation of the east and of the west, the west being very much more luxuriant than the east, which is often absolutely barren for miles. More of the big bird rookeries also are to be found on the west coast, and in their neighbourhood the soil is always considerably fertilised, and vegetation consequently more abundant. Mosses, scurvy grass, tall sulphur buttercups, many saxifrages, small rosaceous plants and the arctic willow carpet and beautify the land. But even on the west coast there are sterile parts, and one not unfrequently passes abruptly from the flowery region into a veritable desert. A sign of luxuriant vegetation in the past in certain places is shown by considerable deposits of peat, which we used for fuel.

Nathorst was probably correct in referring to the rocks at the place he visited south of Cape Cold as silurian rocks of the Hecla Hook series, but, like all others, even this eminent geologist was unable to find any fossiliferous remains. Garwood was probably only partially correct, for, as far as I have been able to judge, the rocks of the Hecla Hook series form the east coast of Prince Charles Foreland except towards the northern portion. I am further inclined to this opinion by the fact that at our base camp I was fortunate enough to discover remains of fossil plants. Many of these are indeterminable, but I obtained good examples of dicotyledonous leaves and, probably, stems: and also what Dr. Peach on rough examination considers may be worm-casts. Mr. Campbell, of the Geological Department of the University, has been good enough to undertake to work through the material and report upon it. Moreover, our chairman. Prof. Gregory, one of our few geologists who has actually visited Spitsbergen and seen the land over which the Scottish party worked last year, promises to inspect the collections, and will doubtless be able to help in making a good report of the geology of the Foreland. Roughly speaking, however, I think I may safely predict that the beds on the northern part of the east coast of the Foreland are tertiary rather than silurian, and are of the same series as exist in King's Bay. Halfway between Vogel Hook and Cape Sitoe are very coarse conglomerates, which are probably archæan and allied to those I have previously met with in Red Bay.

During our stay on the island we made continuous meteorological observations by means of recording instruments, checked by eye observations, at as frequent intervals as other work would allow. We also made a number of astronomical observations at the eight camps which formed the centres of our work in the northern third of the island. These observations have been revised, and I have to thank Mr. Thomas Heath, of the Royal Observatory, Blackford Hill, for working up and classifying the results.

On the 30th August we finally left the Foreland, but with difficulty, on account of four days' very stormy weather, which made it impossible for boats to approach the shore. Even on the 30th we had great 


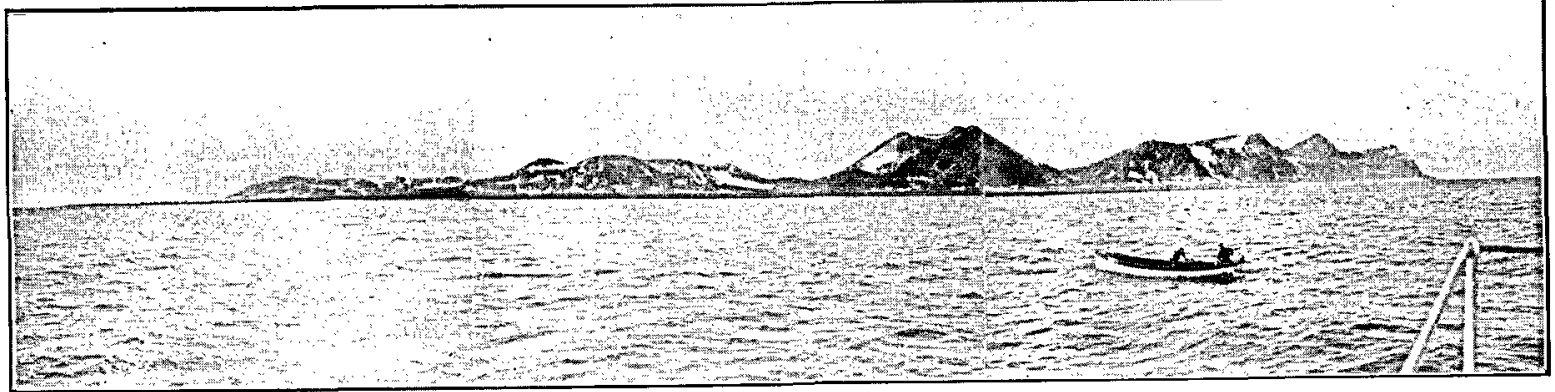

Prince Charles Foreland-10 miles of enst coast, from Vogel Hook southward.

Vogel Irook.

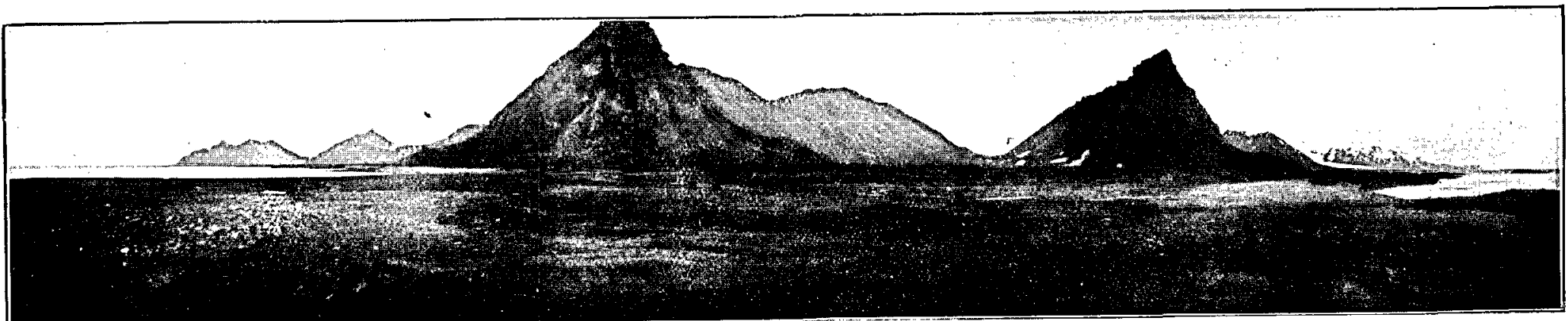

Vogel Ilook.

Prince Charles Foreland--about 30 miles of west coast from Vogel Hook to Cape Cold.

Cape Cold, 
difficulty, having to run the boats through surf, greatly endangering the re-shipping of our scientific instruments and other gear. On the night of the 30th we anchored in a sheltered bay with the Kvedfjord off the large lagoon previously referred to, and during the strong gale and snowstorm recovered one of our boats which we had left in the lagoon a week previously. At $8.30 \mathrm{~A} . \mathrm{M}$. on the 31 st we heaved up anchor and steamed southward towards Ice Fjord, and, sounding frequently, I obtained as our least depth 4 fathoms: but mostly the soundings were over 10 fathoms. We looked into Safe Harbour, and not finding the yacht there, steamed across to Green Harbour, coming alongside Princesse Alice at 4.30 P.M. Fortunately the morning cleared up, and I took some photographs and sketches of the east coast of the Foreland, identifying several peaks I had seen from the northward. I found that several of the peaks seen from the Scottish standard at the south end of the "Base Line" were the furthest south on the island. Consequently, with angles taken at some future time from another suitable point, the position of these peaks will ultimately be very well fixed. On September 2 nd we heaved up anchor and steamed across to Safe Harbour, in spite of very dull weather and a fresh north-westerly breeze. On approaching the bay so much ice from the glaciers was streaming out of $i t$, that the Prince was compelled to abandon his intention of going in, and heading out of Ice Fjord steamed towards Tromsö. At noon on 3rd September we were 30 miles west of Bear Island, sailing with the fresh north-westerly breeze. Dr. Richard found the temperature of the water much cooler in the vicinity of the Bear Island than either to the north or south of it. During the evening the foreyard carried away, but so coolly and systematically was this accident taken in hand that none of us aft knew anything about it until on going up we found the men stowing away and lashing up the yard on deck. On the 4th we sighted the northern coast of Norway, and in sight of the land the Prince made a meteorological balloon ascent to the height of about 15,000 feet. We anchored at Karlsö half an hour after midnight on September 5th. In the morning we took in the trammel net, which had been set after our arrival at Karlsö, and got a good haul of fish, and also a number of other interesting zoological specimens. We reached Tromsö at about 2 P.M., and spent most of the afternoon going over our letters which were awaiting us there. At 6 P.Mr. Captain Bourée took a photograph of all those who had specially helped in the exploration work, and afterwards the Prince entertained Isachsen's and my men in the cabin, toasting us all, and thanking us for the work we had done. He also told us he would have a special medal struck to commemorate the accomplishment of the scientific work that had been carried through on his yacht during the cruise.

Our party on board the yacht, which included representatives from no less than seven nations-a Babel of tongues-was, however, destined to have a gloom cast over it next morning, when Captain Henry Carr, R.N.R., who had sailed for long years with His Highness as shipmaster, was found lying on the floor of his cabin unconscious and paralysed. Fortunately both the Prince himself and Captain Bourée were ex- 
perienced navigators, and there was no difficulty in carrying on properly the conduct of the ship.

On the 10th September we put in at Trondjhem, and next day the Princesse Alice left for Havre, instead of for Leith as was at first intended, on account of the illness of Captain Carr. Thus terminated the happy connection of the Scottish party with the Princesse Alice, Kerr, Miller, and myself returning to Scotland by way of Bergen, Newcastle and Leith.

This is the sum and substance of the Scottish exploration of Prince Charles Foreland, and the summary of our knowledge with regard to it up to the present day. It will be seen that much work still remains to be done, and it is not unlikely that an opportunity may be afforded me, with a larger party, including scientific men, of completing the survey of Prince Charles Foreland under the auspices of that spirited international scientist, His Serene Highness, Albert, Prince of Monaco.

\section{PROCEEDINGS OF THE ROYAL SCOTTISH GEOGRAPHICAL SOCIETY.}

\section{Meeting of Council.}

AT a Meeting of Council, held on Monday, January 28th, The Hon. Lord Guthrie was elected a Vice-President of the Society. The following ladies and gentlemen were elected Members of the Society :-

\begin{tabular}{|c|c|c|}
\hline $\begin{array}{l}\text { Hume Brodie. } \\
\text { MIrs. K. L. Beilby. } \\
\text { James S. Davidson. } \\
\text { Dr. William Paterson. } \\
\text { Alexander Hutcheson, M.A. } \\
\text { A. T. Graham. } \\
\text { Robert Campbell, M.A., B.Sc. } \\
\text { Miss Esther Hope Day. }\end{array}$ & $\begin{array}{l}\text { George Watson. } \\
\text { Miss Elizabeth Rodger. } \\
\text { John M'Lean, M.A. } \\
\text { Robert T. Morrison. } \\
\text { James Wilson. } \\
\text { Rev. W. A. Heard, M.A., LL.D. } \\
\text { Mu's. Lou Henry Hoover. } \\
\text { James Mathieson. }\end{array}$ & $\begin{array}{l}\text { Sir Wm. Willcocks, K.C.M.G. } \\
\text { Miss M. H. L. Clark. } \\
\text { Mrs. Pringle of Whytbank. } \\
\text { Miss Elizabeth R. Barty, M.A. } \\
\text { Miss Margaret P. D. Stewart. } \\
\text { Belpin Behari Ghosal, M.A. } \\
\text { Stuart Foulis. } \\
\text { Fred. J. Pack. }\end{array}$ \\
\hline
\end{tabular}

The following ladies and gentlemen were elected "Teacher Associate" Members of the Society :-

Mrs. A. C. Buchanan.

Miss Ethel M. Lett.

Miss Isabella Goodlet.

H. J. Findlay.

J. B. Innes, MI. A., F.E.I.S.

Duncan Brown, C.M.

Thomas W. Paterson.

John Grant.

Alexander C. S. Scrimgeour, M.A.

A Iexander Sutherland. Miss Margaret F. Anderson.
Walter Burt, MI.A.

Neil Fraser, M.A.

Miss Annie A. Dow.

John Miller Nisbet, M.A., Frederick Mort, M.A., B.Sc., B.Se.

James Graham, M.A.

John Ambrose, M.A.

Donald Maclean, M.A.

Miss Christina A. Cameron, M.A.
George Elder.

Horace F. M. Munro, M.A.

Miss Hannah Watson. F.G.S.

John Frew, M.A., B.Sc.

J. Corrie.

Miss Margaret Johnston, A.L.C.M.

\section{LeCtures in March.}

At Dundee, on the 5th March, Mr. T. G. Longstaff, M.D., F.R.G.S., will deliver a lecture entitled "Tours in Central Himalayas and Tibet." 